\title{
8. Stability, Security and Development in Oceania: Whose Definitions?
}

\author{
Treva D. Braun
}

Stabilité, sécurité et développement en Oceanie: Quelles définitions?

Avec le Plan Pacifique qui fête son cinquième anniversaire en 2010 et les Programmes de Pékin et du Pacifique pour l'égalité des sexes qui célèbrent leur quinzième anniversaire, on a une bonne occasion pour réexaminer certaines des définitions sous-jacentes qui continuent à guider le discours dominant sur le développement et de voir comment les approches régionales pourraient être renforcées afin de mieux rendre compte des intérêts à la fois des femmes et des hommes du Pacifique. Les dimensions clés des questions de développement en matière de sexe, telles qu'elles sont exprimées dans les cadres d'égalité existants, peuvent et devraient être intégrées dans tous les cadres et stratégies de développement dominants, y compris le Plan Pacifique. La période est également propice à la création de mécanismes et de processus clairs auxquels doivent adhérer les dirigeants au plus haut niveau en vue de recadrer le discours national et régional et le système institutionnel de façon que des engagements pris il y a longtemps en matière d'égalité des sexes puissent commencer à animer et guider les progrès de la stabilité, de la sécurité et du développement dans la région. Cet article vise en premier lieu à fournir une réflexion sur les limites du discours régional actuel sur ces questions, ensuite à présenter certains aspects de la recherche et les données les plus récentes qui sont de la plus haute importance pour parvenir à des définitions qui tiennent mieux compte de la question des sexes, et troisièmement à recommander un nouveau modèle régional avec la mise au point de mécanismes de haut niveau acceptés pour appuyer une intégration plus poussée des droits et des voix des femmes dans les processus de développement multisectoriels. Dans cet article, on fait des comparaisons entre le Plan Pacifique en tant que cadre régional principal qui couvre la stabilité, la sécurité et le développement, et les Programmes de Pékin et du Pacifique pour l'Action en tant que cadres principaux qui traitent des dimensions relevant de l'égalité des sexes dans ces mêmes questions. Enfin, cet article présente une critique de l'histoire et de la situation actuelle du Plan Pacifique, avec des propositions pour le renforcer et le consolider. 


\section{Introduction}

Discussions at the most influential levels in the Pacific on stability, security and development are still heavily skewed towards traditionalist masculine understandings of these terms. High level discussions on development, as reflected in their resulting frameworks and resource allocations, focus on economic and public service delivery models, and stability and security are understood primarily as the absence of public financial and economic uncertainty and public or external threats and conflict. While work in those areas is clearly important, the longstanding and now incontrovertible knowledge is that no discussion on these topics can proceed meaningfully without full attention being paid to more expansive definitions, including those grounded in a full understanding of the often differing perspectives of women and men. ${ }^{1}$ 'Development' imperatives and implications are still, often, significantly different for men and women. Similarly, 'stability' and 'security' have both overlapping and divergent meanings for them. Given that women make up half of the population, their definitions in these areas should be driving and informing the development of relevant frameworks and budgets on a fully equal footing.

The aims of this paper are firstly to provide reflections on the limits of the current regional discourse on these topics, secondly to provide some of the latest research and data of critical importance to more gender-responsive definitions, and thirdly to recommend a new regional paradigm including the development of agreed high-level mechanisms to support stronger integration of women's rights and voices into multi-sectoral development processes. The paper makes comparisons between the Pacific Plan as the main regional framework covering stability, security and development and the Beijing and Pacific Platforms for Action as the main policy frameworks addressing the gender dimensions of these same issues. A critique of the history and current status of the Pacific Plan, with suggestions for strengthening and bolstering it, is presented.

With the Pacific Plan marking its fifth anniversary in 2010 and the Beijing and Pacific Platforms for gender equality celebrating their fifteenth anniversary, it is a good time to re-evaluate some of the underlying definitions which continue to guide mainstream development discourse, and to consider how regional approaches might be strengthened to better account for the interests of both Pacific Island women and men.

\footnotetext{
1 Even women and men are far from being homogenous groups with identical issues and experiences, and such categorisations risk the very real limits of essentialism. People's perspectives vary according to age, ethnicity, socio-economic status, rural/urban locale, disability and sexual orientation among others. Even within those categories people are diverse. Nonetheless, there are certain widely shared issues that permit broad-based gender analysis, and this paper will focus on those.
} 
The key gender dimensions of development issues, as expressed in existing gender equality frameworks, can and should be integrated into all mainstream development frameworks and strategies, including the Pacific Plan. The time is also ripe for the development of clear mechanisms and processes, to be endorsed by leaders at the highest levels, for reframing the national and regional discourse and institutional architecture so that long-standing commitments to gender equality can begin to systematically inform and guide the advancement of stability, security and development in the region.

\section{Defining Moments}

It is vital to the effectiveness of any dialogue or process that those involved in it, and those impacted by it, have a common and complete understanding of the underlying definitions of the issue under discussion. Many, however, are begun without any opportunity for preliminary agreement on terminology. Further, discussion topics and their definitions often become presumed truths set for a wider group by a smaller and more powerful group, particularly where there has been an advance filtering by virtue of an agenda setting process. This is certainly the case with discussions on development, stability and security, where those setting the agenda, namely those in senior decisionmaking positions in government and in bilateral and multi-lateral donor and development agencies, are also the ones deciding upon or making assumptions about the basic underlying definitions from which all further discussions flow. Unless those definitions are accurate and inclusive, the entire dialogue and its outcomes can be highly problematic for certain groups.

The Pacific Plan(Pacific Islands Forum Secretariat 2005a) - the main regional framework addressing stability, security and development - provides a useful illustration of the problems that can arise from incomplete definition-setting processes. ${ }^{2}$

The identification of 'regional priorities' for the Pacific was the first of many definition-setting processes over the course of the Pacific Plan's development from which the voices of Pacific Island women and regional gender equality experts were largely excluded. An Eminent Persons Group (EPG), ${ }^{3}$ appointed

\footnotetext{
2 It is not the intention of this paper to undertake a comprehensive analysis of the Pacific Plan, though it is clear that the Plan urgently requires revision based on a comprehensive gender and human rights analysis to make it responsive to concerns widely expressed by Pacific women's groups. The Plan's weaknesses from a gender perspective have been the subject of earlier scholarly commentary (Huffer 2006). These and other critical inputs have scarcely been taken up to date.

3 The EPG was comprised of Sir Julius Chan (former Prime Minister of Papua New Guinea), Bob Cotton (former Australia High Commissioner to New Zealand and special envoy to Papua New Guinea), Dr Langi Kavaliku (Pro-Chancellor of the University of the South Pacific and a former Deputy Prime Minister of Tonga), Teburoro Tito (former President of Kiribati), and Maiava Iulai Toma (Samoa Ombudsman and former Ambassador to the United Nations).
} 
to review the Pacific Islands Forum and make recommendations for addressing 'key regional issues', recommended defining the four priorities of the Forum as economic growth, sustainable development, governance and security, and these subsequently became the four pillars of the Pacific Plan adopted by the Pacific Islands Forum Leaders. As such, the Pacific Plan as endorsed provides that its objective is to 'enhance and stimulate economic growth, sustainable development, good governance and security for Pacific countries through regionalism.'

While the EPG laudably recommended that the Forum 'address the low participation of women in all levels of decision-making processes and structures, ${ }^{4}$ it did not seek to ensure (and the Forum did not require) that the very decision-making structures that were already in existence or about to be launched in furtherance of the elaboration of the Pacific Plan were gender balanced or had the relevant gender expertise, and most of the relevant bodies were either exclusively or predominantly constituted by men.

A Task Force was charged with developing the Pacific Plan based on terms of reference which themselves constituted a definition-setting exercise. The terms of reference instructed the Task Force to consider strategies for better regional cooperation 'taking into account the broader international environment and agreements in which the Forum members participate' and identified two international development frameworks as being of primary importance: the 2002 World Summit on Sustainable Development and the 2000 Millennium Declaration (Pacific Islands Forum Secretariat 2005b: para 4). While both of those contain some gender equality language, neither provides a comprehensive and transformative agenda for rectifying gender inequalities across the development spectrum, in keeping with human rights principles, in the way that the World Conference on Women and its Declaration and Platform for Action - which all Forum Island Countries endorsed - did in Beijing in 1995 (United Nations 1996). One wonders whether the Beijing Platform for Action (BPA) might have been considered one of the defining international agreements of primary importance for the elaboration of the Pacific Plan - a regional framework in support of 'peace, harmony, security and economic prosperity for all Pacific people' had women participated on an equal footing in setting the regional priorities and drafting the terms of reference, and if it had been what the Pacific Plan might look like today. Instead, the Pacific Plan terms of reference only briefly recognised the 'importance of women and gender'.

\footnotetext{
4 As well as the reduction and elimination of domestic violence, and the improvement of women's literacy and health status.

5 The Forum Leaders' 'Vision' as expressed during the 6 April 2004 Auckland Retreat which set the development of the Pacific Plan in motion begins: 'Leaders believe the Pacific region can, should and will be a region of peace, harmony, security and economic prosperity, so that all of its people can live free and worthwhile lives.'
} 
Perhaps the most defining of the background papers which informed the Pacific Plan's development is an Asian Development Bank and Commonwealth Secretariat joint report analyzing issues and possibilities for achieving the Leaders' Vision based on a series of working papers (Asian Development Bank and Commonwealth Secretariat 2005). Of the eighteen working papers that fed into that joint report, not one is dedicated to the options and benefits that regionalism could present for eradicating gender inequality in the Pacific, and with the exception of a paper on bulk petroleum procurement which links energy efficiencies with social improvements including achievement of the Millennium Development Goals (Morris 2005), none even mentions gender or uses basic sex disaggregation within its thematic topic. Rather, they focus on gender-blind infrastructure and sectoral cost-benefit analyses.

The gap is glaring. For instance, whereas several quantitative assessments were conducted on issues ranging from telecommunications deregulation (McMaster 2005) to the economic cost of governance failure in four Pacific countries (Duncan 2005), and despite recognition in the main body of the joint report that discrimination against women in employment is widespread (Asian Development Bank and Commonwealth Secretariat 2005: 29), there was no assessment done of the economic cost of systemic sex discrimination and the potential benefits to the region of its eradication. As will be discussed below, within two years of the endorsement of the Pacific Plan such a study for the AsiaPacific region as a whole estimated billions of dollars in losses each year due to discrimination against women and girls in education and the labor force alone. Similarly, the fisheries sector analysis fails to mention much less address the issue of prostitution of women and children on foreign fishing vessels in Pacific waters. Not surprisingly, these and other issues which are disproportionately women's concerns remain severely under-addressed in the Pacific Plan and in other mainstream Pacific development spheres.

The concerns and priorities specific to the female half of the Pacific population were largely left to public consultations, discussions that were premised on a document the parameters of which had been defined without gender or human rights analysis or women's meaningful involvement. Pacific women and gender experts had neither agenda-setting nor priority-balancing influence. They were merely one of many interest groups or 'non-state actors' - alongside youth, the disabled etc. - the inputs of which those in control of the agenda and of determining the relative importance of various submissions could accept or reject. ${ }^{6}$ This is partly the fault of skewed leadership structures in the Pacific,

6 Indeed, among the submissions and recommendations of gender experts including the Regional Rights Resource Team, UNIFEM Australia and a joint submission by the Fiji Ministry of Women, Social Welfare and Poverty Alleviation on behalf of a number of women's organisations, virtually all were apparently rejected. 
and partly that of insufficient planning processes. Among others, consultations were criticised for being rushed, leaving little time for meaningful input and analysis (Huffer 2006: 161).

Unsurprisingly, the failure of the Pacific Plan to properly address women's issues, as will be discussed below, flows directly from this series of oversights. Unfortunately, few if any of the weaknesses have been rectified in the processes that have taken place during the first five years of the Plan's existence. Encouragingly, however, the Pacific Plan is a 'living document' which has the potential for immediate and high impact improvement.

\section{Towards More Inclusive Definitions}

The definitions and underlying assumptions in the Pacific Plan and other key frameworks, including most national development strategies in the region, about what constitutes stability, security and development, as well as the delineation and prioritisation of necessary initiatives in these areas, are largely gender blind. For these frameworks to acquire legitimacy as being relevant and responsive to Pacific Island women, they arguably require a wholesale re-drafting through a wholly reconstituted design process.

However, even if one is limited to working within the existing frameworks, a number of substantive improvements are possible. For instance, the BPA and its regional counterpart, the Pacific Platform for Action on Advancement of Women and Gender Equality (PPA) which was first adopted at a Pacific Ministerial Meeting on Women in 1994 as part of the regional preparations for the Fourth World Conference on Women and subsequently revised in 2004 both versions pre-dating the adoption of the Pacific Plan - address identical issues as the Pacific Plan but from a very different angle (Secretariat of the Pacific Community 2005). That angle is a critical piece, roughly half the size, of the regional development puzzle.

However, among all of the Pacific Plan's initiatives for 'immediate implementation between 2006-2008', for 'agreement in principle' and for 'further analysis', there was no direct reference to implementation of the BPA or PPA. ${ }^{7}$ This contrasts with the multitude of references in the Plan to the need to develop and implement other regional strategies and action plans such as the Pacific Islands Energy Policy and Strategic Action Plan, the Pacific Regional Action Plan on Sustainable Water Management, the Pacific Climate Change Framework,

7 The December 2004 draft of the Pacific Plan included within the Sustainable Development goal the following 'medium-term benefit': 'Specialised support provided to help Pacific governments take the implementation of CEDAW, the Beijing Platform for Action and the Pacific Platform for Action further.' This was later removed. 
the Pacific Disaster Risk Reduction and Disaster Management Framework for Action, the Forum Principles on Regional Transport Services, the HIV and STI Strategy, and the Regional Digital Strategy.

The BPA and PPA are extensive, transformative and cross-cutting policy frameworks informed and guided by international human rights law on the right to non-discrimination on grounds of sex. Their implementation, however, has been extremely weak in the Pacific (Secretariat of the Pacific Community 2010a). Among the barriers to better implementation are that they have not had the engagement of political leaders, they are mere calls for action rather than agreements for action, they remain the purview of highly marginalised women's departments despite their expansive, multi-sectoral application, and while they support the implementation of legally binding instruments such as the UN Convention on the Elimination of all forms of Discrimination Against Women $(\mathrm{CEDAW})^{8}$ they have no high level accountability. Activities under them have been uneven at best, and progress has been largely disappointing.

As such, an integration of the key thematic recommendations of the BPA and PPA into the corresponding thematic areas of the Pacific Plan, and the parallel development of clear regional multi-sectoral strategies for achieving gender equality commitments, would bring gender concerns into the mainstream and onto a more level playing field with other areas of priority concern in the region. These measures could go a long way towards overcoming both the gender deficiencies of the Pacific Plan and the lack of movement on the BPA, PPA and CEDAW.

A few non-exhaustive examples will be discussed below. Several of them do not fit neatly into just one of the pillars or strategic objectives of the Pacific Plan. They are intended here as illustrations of the history and current status of regional development paradigms from a gender perspective and of potential avenues for shifting those paradigms, all of which would require more detailed analysis and discussion if and when the Leaders take up the call to gender mainstream the Pacific Plan and develop the necessary mechanisms and strategies.

8 In force throughout the Pacific with the exception of Nauru, Palau, Tonga and the American territories of American Samoa, Commonwealth of Northern Mariana Islands and Guam. 
Politics, Development and Security in Oceania

\section{Stability and Security}

Security is defined in the Pacific Plan as 'the stable and safe social (or human) and political conditions necessary for, and reflective of, good governance and sustainable development for the achievement of economic growth. ${ }^{\prime 9}$

The ADB-Commonwealth Secretariat joint report's first working paper notes that 'security is no longer viewed in the narrow sense of merely defending a state from external or internal threats of a military nature. Rather, it is now realised that security is closely linked with generating conditions that free people from fear and misery arising from various causes' (Hassall 2005: 1). It establishes that while questions about security had been considered in a number of earlier Pacific Islands Forum documents the term was not fully defined in any of them, though the range of examples given from those documents makes it clear that 'security' carried a presumed definition limited to internal or external threats of a public nature such as natural disasters, threats to national integrity, and ethnic or social tension.

Despite the working paper's urging that security issues were most likely to arise from internal issues such as land pressures, economic disparities and ethnic division and that as such 'security responses must be re-oriented to meet ... internal threats rather than external ones' (Hassall 2005: 4), there is no mention of the need to address the range of gender-specific internal security concerns. For most women, the biggest human security risks come from within their borders, communities and often their own home. Yet these security issues which are of particular and heightened daily concern to women, and which have been the subject of countless international and regional research and lobbying efforts, did not register as key causes of the 'fear and misery' from which any security framework ought to free people. In the end, the joint report, while acknowledging that security has become a multifaceted concept, expressly elected to focus on 'those aspects of security that relate to dedicated law and order institutions - e.g., police, military, border enforcement, customs, and intelligence services - as well as the more dramatic manifestations of insecuritye.g., terrorism, transnational crime, civil conflict, secessionist movements, and domestic political instability' (Secretariat of the Pacific Community 2005: 170). It viewed broader 'comprehensive' or 'human' security issues as falling within the other pillars of the Pacific Plan.

9 It is curious and perhaps telling that security in the Pacific Plan is linked specifically to an end goal of 'the achievement of economic growth' rather than being an end in itself. 
The result is that security remains traditionally and narrowly defined in the Pacific Plan. Its single strategic objective is improved political and social conditions for stability and safety', with the enumerated security initiatives focusing on maritime, aviation, border and bio-security issues.

Among the stability and security concerns specific to or disproportionately faced by Pacific women are lack or erosion of land and housing rights, personal economic insecurity, and lack of basic physical security, none of which are directly addressed as key initiative areas in the Pacific Plan.

Land and housing insecurity is a major and growing concern for many Pacific Island women. Examples vary from the Tongan extreme where women are not legally allowed to own or inherit land to traditionally matrilineal land systems such as those in the Republic of Marshall Islands, Solomon Islands and Vanuatu where women's traditional ownership of land in complementary systems of custodianship and decision-making with men has increasingly been eroded due to the introduction of the cash economy, large scale extractive industries, and women's exclusion from modern decision-making bodies including land authorities (Stege, et al. 2008). In many Pacific contexts, women do not enjoy equal housing rights.

The need to ensure women's equal access to land and other resources, and avenues for doing so, are expressed in the BPA (Strategic Objectives A.1-A.4). It recognises that women's poverty is directly related to lack of access to land ownership and inheritance and recommends legal and administrative reforms to protect women's land rights. At their 2008 meeting in Niue, Forum Leaders directed that land be considered as an emerging region-wide priority, yet made no mention of women's specific land insecurity issues, citing only 'migration, urbanisation, increasing numbers of disenfranchised youth, and population displacement caused by climate change and natural disasters' among the list of land-related security concerns (Pacific Islands Forum Secretariat 2008: 14-15). The meeting communiqué did, however, attach guiding principles in respect of land management and conflict minimisation, which include provision that consensus-based solutions to land conflict should include strengthening of customary and formal institutions and decision-making processes that, among others, 'reflect principles of gender equity', and that processes for clarifying customary land tenure would be consistent with CEDAW for those countries that have ratified it (Pacific Islands Forum Secretariat 2008: 19).

Economic insecurity is another major issue disproportionately affecting women in the Pacific Islands region. In virtually all countries and territories, women's access to and participation in the labor market is still significantly lower than men's, as is their participation in wage employment in the non-agricultural sector, as illustrated in Figures 1 and 2. 
Sex disaggregated labor force data on wages are not systematically collected in the Pacific and need prioritisation, however estimations show that even for women earning an income their earning power is a fraction of that of men (see Figure 3).

This structural inequality is exacerbated for women in situations of economic downturn, as they typically suffer the greatest adverse impact of generalised economic insecurity including under the present global financial crisis.

\section{Figure 1: Labour Force Participation Rate}

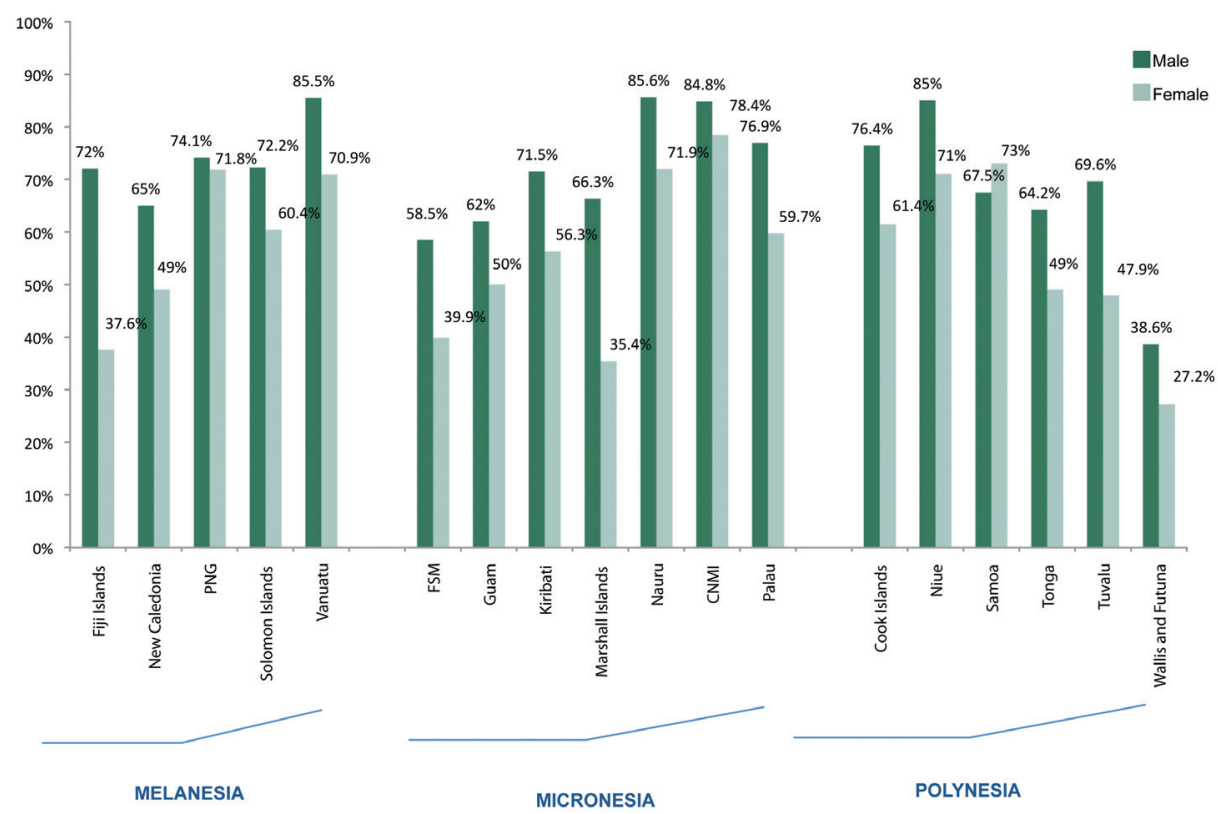

Source: SPC PRISM.

Economic imperatives for Pacific women as expressed in the PPA include attention to women's contributions to the informal sector, equal opportunity of men and women in employment, better collection and analysis of gender specific labor force and economic data, and women's participation in income generating activities in rural areas and disadvantaged households (Secretariat of the Pacific Community 2005: paras 89-90). Poverty eradication priorities include provision of government-sponsored social schemes for male and female wage earners in the private sector and enhancements to financial literacy at the community level (Ibid: paras 91-94). The BPA also draws the link between women's poor economic status and their risk of sexual exploitation (Strategic Objectives A.1-A.4), a common and increasing security risk for both women and girls in the region (see UNICEF, UNESCAP and ECPAT 2006). 
Figure 2: Share of Females and Males in Wage Employment in the Nonagricultural Sector

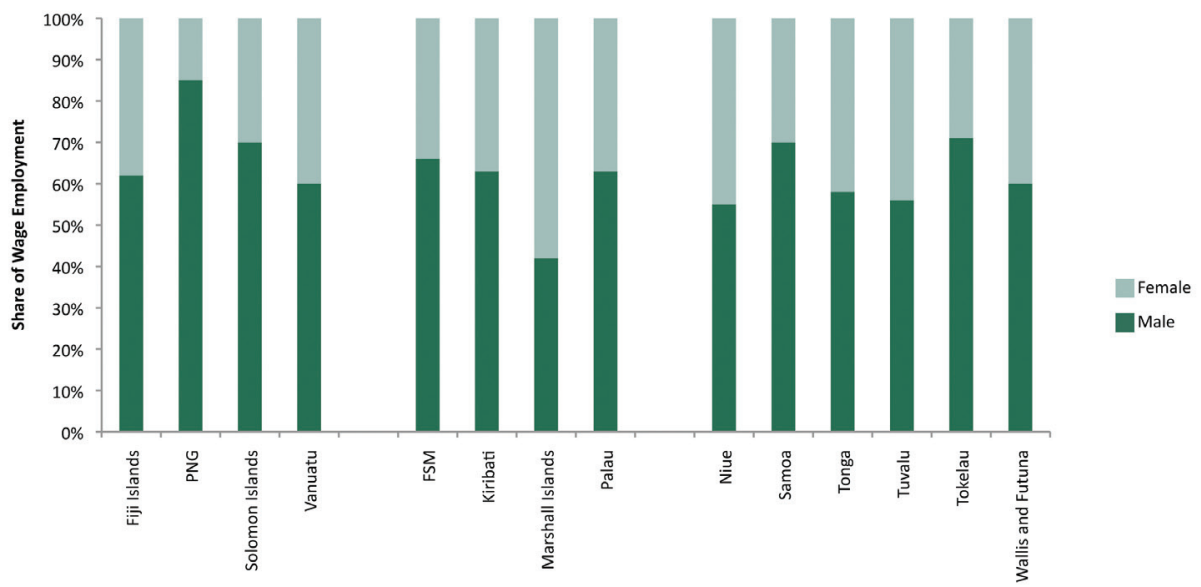

Source: SPC PRISM.

Figure 3: Ratio of Estimated Female to Male Earned Income

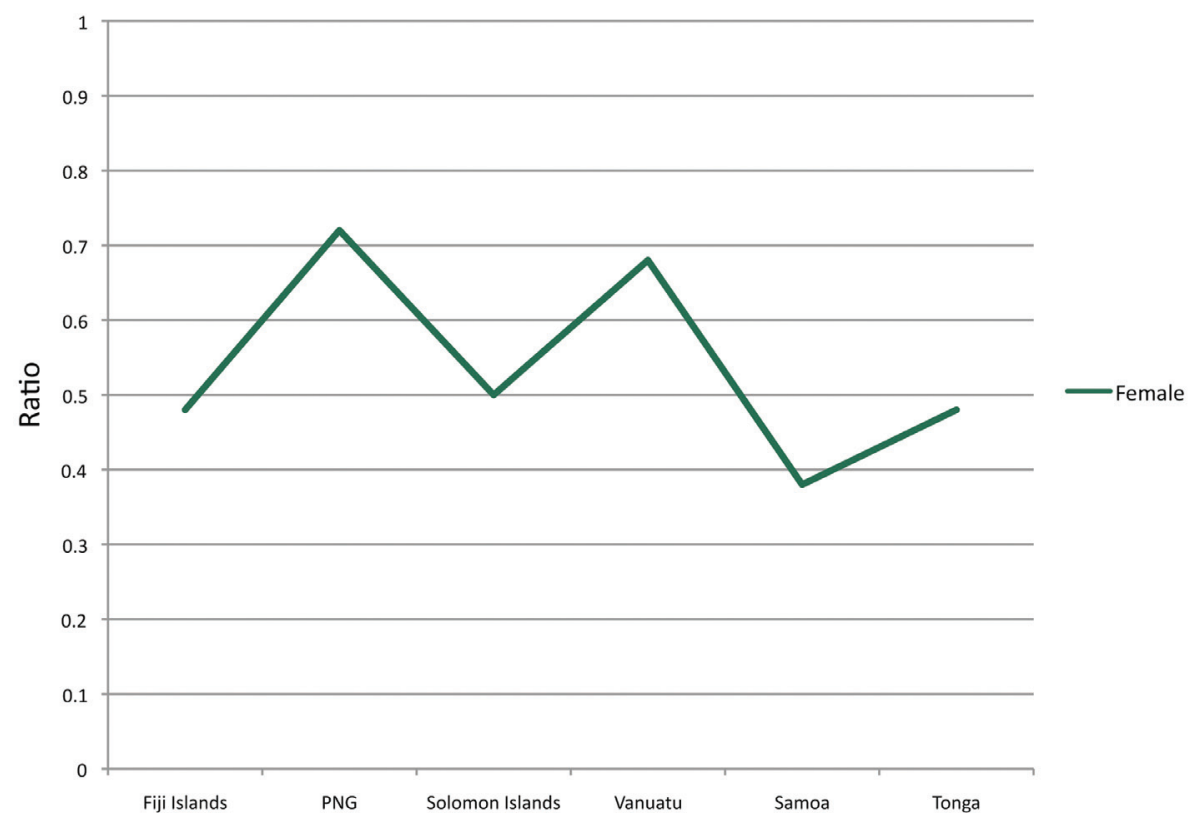

Source: UNDP Human Development Report 2007-2008, pp. 330-33. 
Personal physical security in the home and community is a serious daily issue for many Pacific women, and one that is still largely unaddressed. For many, it is the police and military themselves who present a major security risk (see Human Rights Watch 2006). For more still, violence in the home presents the single biggest risk to physical security. Domestic violence in some countries in this region is occurring at among the highest rates in the world, much more frequently than any public conflict or external security threat. Three countries, one per sub-region, have conducted national level surveys using a globally comparable World Health Organization survey methodology: Samoa (Secretariat of the Pacific Community, United Nations Population Fund, and Government of Samoa 2006), Solomon Islands (Secretariat of the Pacific Community and Government of Solomon Islands 2009) and Kiribati (Secretariat of the Pacific Community and Government of Kiribati 2010). Demographic and health surveys in the region are also starting to ask questions about the safety of women at the household level (Secretariat of the Pacific Community and Government of Republic of Marshall Islands 2008; Secretariat of the Pacific Community and Government of Tuvalu 2009). The results show that up to two thirds of women experience physical and/or sexual violence by an intimate partner in their lifetime (see Figure 4). Up to 60 per cent experience physical violence, ${ }^{10}$ up to 55 per cent experience sexual violence, and as many as half have experienced forced intercourse. Between 20-40 per cent of women aged 15-49 in Kiribati and Solomon Islands reported having been sexually abused before the age of 15. Many women suffer beatings by their partners during pregnancy putting not only the mother's but also the child's health and safety at risk. The national surveys show that the violence suffered by these women is more likely to be severe violence such as punching, kicking or having a weapon used against them, rather than more moderate forms of violence.

These issues are all compounded by the lack of legal protection in many Pacific Island countries. For example, at least three countries have no constitutional prohibition on sex discrimination, almost none have comprehensive domestic violence legislation, none have comprehensive integrated legislation covering all forms of violence against women, and marital rape is not criminalised in several countries. Even when legislation is in place it is often very poorly enforced. Virtually no strategies, policies and action plans to eliminate violence against women exist in the region.

10 Between 50-70 per cent (and usually much closer to the 70 per cent mark) of both men and women surveyed agree with at least one 'justification' for such violence, and the most common justifications are things like 'disobedience', 'unfaithfulness' and 'neglect of household duties', indicating a very high socialisation of both inequality between women and men in the household (women are expected to 'obey' their husbands rather than being equal partners) and of violence as a means for resolving disputes. This socialisation is reflective of the longstanding unequal power relations between men and women and is a mechanism by which women are kept in a subordinate position compared with men. 
Figure 4: Prevalence of Lifetime Physical and/or Sexual Violence by an Intimate Partner, Among Ever-partnered Women

Global WHO comparisons

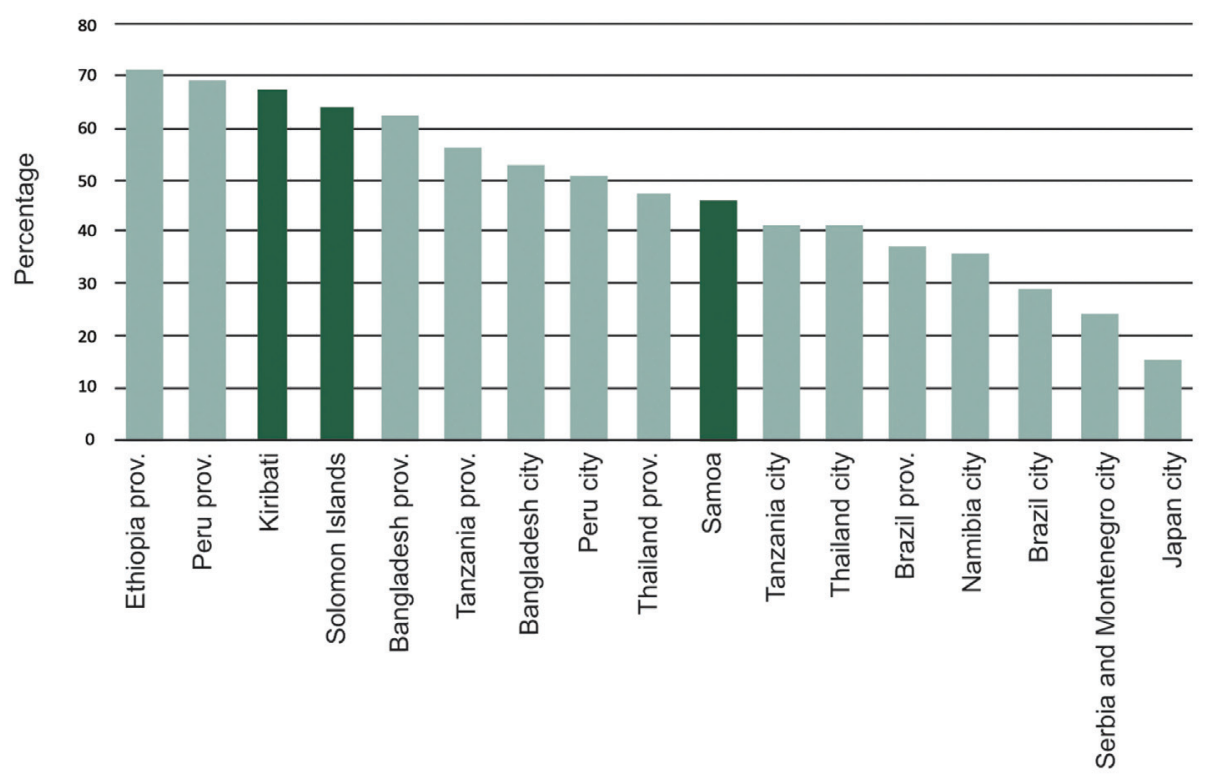

Sources: World Health Organization, WHO Multi-country Study on Women's Health and Domestic Violence against Women: Initial results on prevalence, health outcomes and women's responses (2005); SPC, UNFPA, Government of Samoa, The Samoa Family Health and Safety Study, 2007; SPC and Government of Solomon Islands, Solomon Islands Family Health and Safety Study, 2009; SPC and Government of Kiribati, Kiribati Family Health and Safety Study, forthcoming.

In addition to the significant personal security risk and high social costs of violence against women, the financial cost to Pacific Island economies is staggering. The Reserve Bank of Fiji estimated that violence against women costs the Fijian economy between FJD300-500 million per year, which at the low end amounts to seven per cent of GDP (Jalal 2010). Those estimates are higher still if opportunity costs are considered.

Despite all of this, the only mention in the Pacific Plan of violence against women is in one of several 'milestones' for Security Initiative 13.3 ('Strengthen law enforcement training, coordination and attachments'), namely through regional training courses on family, domestic, gender and sexual violence. All other areas of security are addressed through specific initiatives containing robust language such as 'develop and implement strategies and associated legislation' (for maritime and aviation security) with a clear milestone of having legislation developed by 2008; 'implement the Pacific Islands Regional Security Technical Cooperation Strategy' (in respect of border security, including for transnational crime and bio-security); and 'develop and implement policies and 
plans' (in relation to biosecurity, urbanisation and mitigating natural disasters). If women's physical security risks had been on an equal footing perhaps they would not have been limited to a milestone of training courses but would have had clear initiatives for the enactment of appropriate legislation by a fixed target date and the development of strategies, policies and plans to eliminate all forms of violence against women.

The unique security issues faced by women are squarely addressed in both the BPA and the PPA. The BPA acknowledges that acts or threats of violence against women 'instil fear and insecurity in women's lives and are obstacles to the achievement of equality and for development and peace' (BPA, Critical Area of Concern D: Violence against Women: para 117). In keeping with human rights standards, both frameworks address violence against women in both the private and public spheres including in conflict situations, and provide recommended strategies for eradicating it (Secretariat of the Pacific Community 2005: paras 49-56 and 113-121).

Many Pacific women also experience high physical security risk as a result of poor sexual and reproductive health and rights. Eleven out of 21 Pacific Island countries and territories are ranked as being in either a high or very high reproductive risk category (Family Planning International 2009). Key causes include low contraceptive prevalence rates, high teenage fertility rates, increasing rates of sexually transmitted infections including HIV, poor access to antenatal care, poor access to emergency obstetric care, and restrictive abortion legislation, all of which contribute to poor maternal health and often to maternity related deaths. Underpinning the risk are various persistent forms of discrimination against women (Secretariat of the Pacific Community 2009). The BPA and PPA outline the major contributing factors to maternal risk, including social determinants, and the necessary measures for ensuring women's physical reproductive security (Secretariat of the Pacific Community 2005: paras 73, 79; BPA, Strategic Objectives C.1-C.5).

All of this should be informing both the definition and prioritisation of core regional security issues under the Pacific Plan and the elaboration of comprehensive initiatives to be agreed by Forum Leaders. However, while the EPG report recommended that the Forum address the reduction and elimination of domestic violence and the improvement of women's health status, neither of these made it into the Pacific Plan as priority objectives. Indeed, none of the gender specific security concerns of women made it in under any of the four pillars.

Certain issues such as violence against women are gaining some attention amongst regional leaders. For instance, recently the Forum Regional Security Committee - the principal forum for setting the regional security agenda - has 
given a slot on the 'day two' agenda (when 'soft' human security issues are discussed) to women, peace and security issues including domestic violence. It has yet to appear on the main agenda where 'core' security issues are discussed, demonstrating the continued resistance to seeing women's security as a core regional concern. At the 2009 Pacific Islands Forum meeting, Forum Leaders acknowledged that 'sexual and gender-based violence (SGBV) is now widely recognised as a risk to human security and a potential destabilising factor for communities and societies alike' (Pacific Islands Forum Secretariat 2009, para 63) It was described as a 'sensitive issue in most Pacific cultures' that required 'national ownership' (Ibid.: paras 63-64). The meeting communiqué stops short of prioritising the elimination of violence against women as a core regional security concern. This contrasts with the outcomes of other thematic discussions such as disability, on which Leaders agreed that a Regional Disability Strategy should be considered (Ibid.: paras 33-34), and on Influenza A ( $\mathrm{H} 1 \mathrm{Nl}$ ) in respect of which they called for a 'more coordinated regional approach' in part due to how stretched national health administrations are and the limits that has on their ability to respond independently with any great effect (Ibid.: para 24), a situation that is certainly mirrored in national departments for women.

The key structural problem, of course, is that even when gender issues get on high-level agendas, they get there in an ad hoc and uncertain way through women's rights advocates biting at the heels of existing structures and frameworks that are not designed to take proper account of women's issues in the first instance. As such, women continue to be an afterthought, entering via the side door a dialogue that got underway with a set of presumed definitions well before they arrived.

Several of these obstacles could be overcome by explicitly integrating the gender-specific security issues discussed above into the security pillar of the Pacific Plan as core regional security issues. Parallel with that, a set of agreed regional processes could provide for, among others, standardised enhancements to data collection including wage gap and gender-based violence data; the development of model legislation including to criminalise and punish all forms of violence against women, to protect women's reproductive health rights, to ensure equal employment opportunities and social benefits, and to guarantee women's land and housing rights; and the elaboration of more cost-effective regional campaigns to create awareness of women's unique security concerns.

\section{Governance}

Good governance and sustainable development form part of the Pacific Plan definition of security, both of the former being pre-conditions for and results 
of the latter. Good governance is defined as 'the transparent, accountable and equitable management of all resources. Good governance is a prerequisite for sustainable development and economic growth.'

Women's lack of voice and influence in governance structures is a major concern in the region, calling into question the legitimacy of virtually all resource management and other governance processes from an accountability and equity perspective. Although small advances are being made, women are still excluded or restricted in their access to most decision making structures across the micro, meso and macro levels from the household and customary and religious institutions to local and national government and regional organisations. For example, the Pacific Islands region has the worst record for gender-balanced parliaments anywhere in the world. As Figure 5 shows, Pacific Island countries as a whole stayed stagnant between 1995 and 2008 with an average of only 2.5 per cent of seats in national parliaments held by women.

Figure 5: World and Regional Averages of Women in Parliaments, 1995-2008

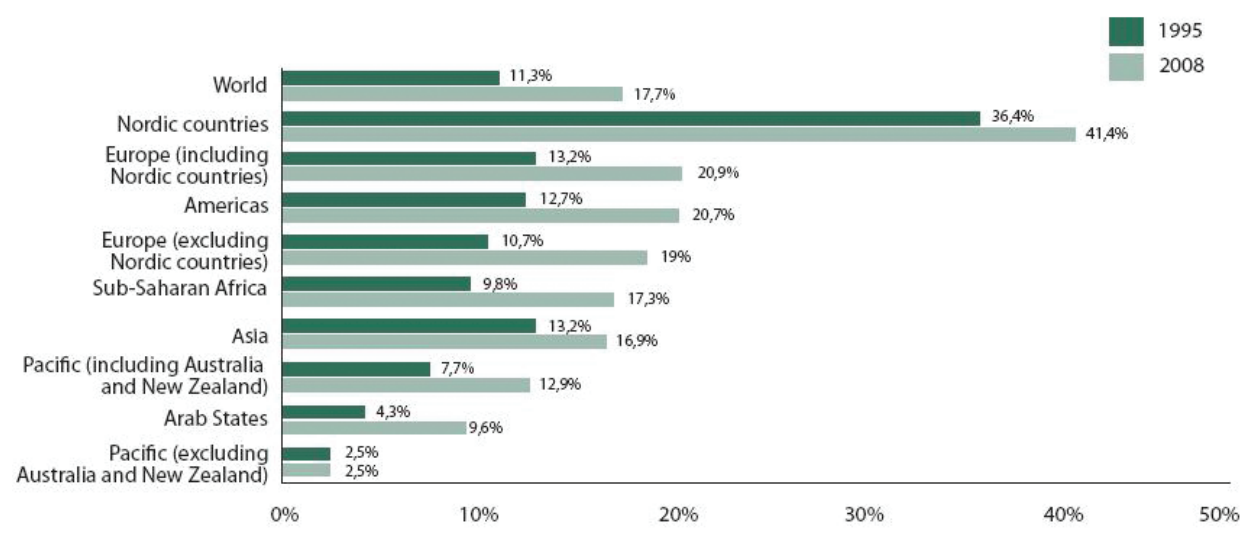

Source: Inter-Parliamentary Union, Equality in Politics: A Survey of Women and Men in Parliaments, 2008, p. 15.

By 2009, the Pacific Islands countries had inched up to an average of 4.2 per cent of seats held by women, still coming in at less than half that of the Arab states. ${ }^{11}$ The notable exception in the region has been the French territories. ${ }^{12}$ While France's parity law seems to have done little to bring greater gender balance

\footnotetext{
11 The figures for Fiji are based on the 2006 Parliament, prior to the December 2006 military coup. To date there is still no democratically elected government in Fiji.

12 The French, American, New Zealand and British territories in the Pacific are not included in the regional or international women in parliament statistics since they are not sovereign nations. Figure 6 however illustrates the data for all Pacific Island national and territorial legislatures.
} 
in the national legislature, ${ }^{13}$ it helped New Caledonia's Congress and French Polynesia's Assembly achieve 43 and 56 per cent, respectively, of seats held by women as of 2009 (see Figure 6).

\section{Figure 6: Number of Seats Held in National and Territorial Legislatures in the Pacific Islands (Male/Female), October 2009}

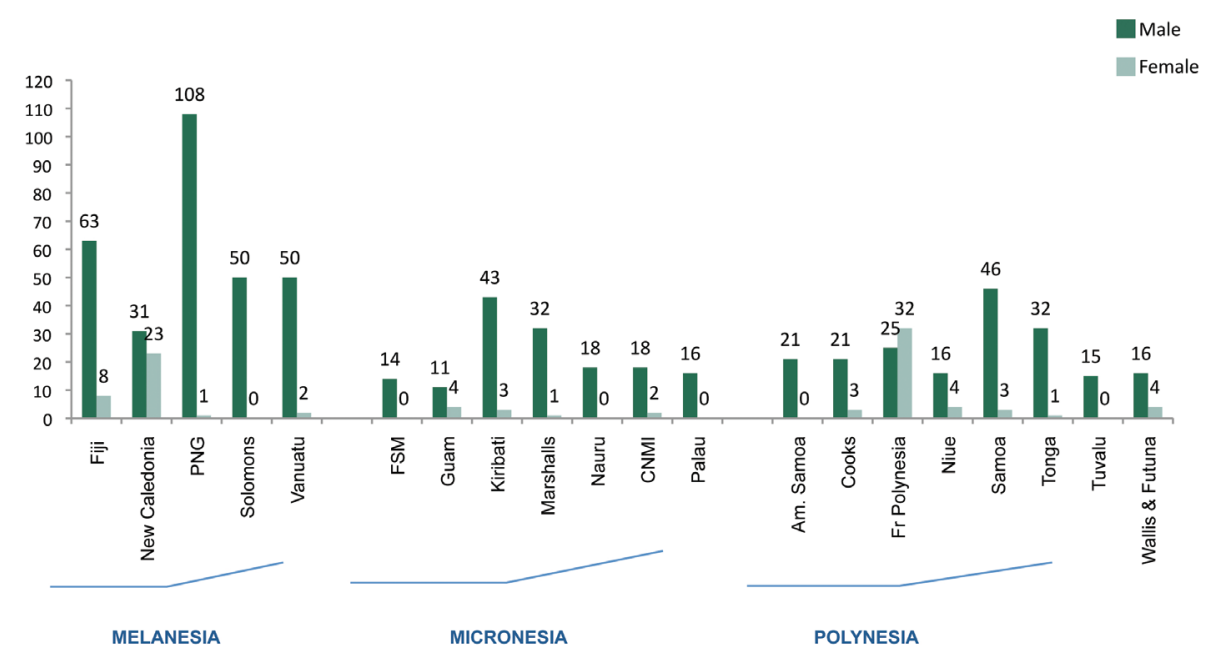

Sources: United Nations Development Programme and Pacific Islands Forum Secretarial, Utilising Temporary Special Measures to Promote Gender Balance in Pacific legislatures; A Guide to Options, 2008; Secretariat of the Pacific Community government focal points.

At the household level, while women in some countries such as Samoa and Cook Islands fare much better, many others in the region still have diminished decisionmaking control over issues ranging from household finances and health care to how to spend their social time (Secretariat of the Pacific Community 2010). In some countries and territories customary leadership is restricted to men, while in others there is greater though still imperfect balance. As noted earlier, women's strong traditional role in land ownership and decision-making in matrilineal societies is being eroded and is in urgent need of protection and strengthening. Religious institutions are heavily skewed towards male leadership and decisionmaking. The highest levels of decision-making in regional organisations like the

13 The 2000 French law on parity requires political parties to have 50 per cent of each sex on their list of candidates, alternating the names of male and female candidates, to increase the likelihood of gender balance in elected positions. In certain cases it is merely a disincentive approach, with political parties who do not comply simply being subject to a fine. Many wealthy parties in France have chosen to pay the fine rather than comply with the object and purpose of the law. 
Politics, Development and Security in Oceania

Pacific Islands Forum Secretariat (PIFS), the Secretariat of the Pacific Community (SPC) and other Council of Regional Organisations in the Pacific (CROP) agencies are heavily male dominated. ${ }^{14}$

These are just a few examples of the range of governance and decision-making spheres that directly impact women's lives but in which they lack equal (and in some cases any) voice and influence, and which presumably contributed to the EPG's recommendation that 'the Forum needs to acknowledge and encourage the participation of women in decision-making at all levels'.

The Pacific Plan, however, was eventually restricted to an initiative to develop 'a strategy to support participatory democracy and consultative decisionmaking (including NSAs, youth, women and disabled), and electoral processes'. This is a significantly watered down approach which not only lumps women in with minors and civil society, it reinforces the faulty yet tenacious notion that provided women are consulted governance systems will be equitable and accountable to them. The Pacific Plan also makes no reference to the broader range of decision-making levels to which women have no or unequal access.

The 2007 Vava'u Decisions which outlined Pacific Plan priorities for the ensuing twelve months included only a single gender-specific agreement (under 'governance'), namely to 'explore ways to enhance participation, particularly by women, in decision-making processes and institutions, and in particular parliamentary processes' (Pacific Islands Forum Secretariat 2007: 14). However, in the 2008 Pacific Plan Annual Progress Report, in which extensive detail is provided on key achievements over the reporting period and anticipated progress in the following reporting period, there is no mention of any achievements or anticipated progress on this issue. Similarly, the 2009 Annual Progress Report is completely silent on gender and women's issues, including under the governance priorities (see See Pacific Plan progress reports at http://www.pacificplan.org/). While work in support of women in parliament is being done in the region including through PIFS, it is not registering as a priority for Forum or regional leaders nor is it being highlighted in Pacific Plan annual reporting processes.

The BPA and PPA provide practical frameworks for transforming decision-making structures at all levels including the political, judicial, private sector, community and household levels. They recognise the need to consider attitudinal, cultural and religious factors surrounding the political advancement of women, and to enhance those practices which are supportive while removing with urgency those which disadvantage women. Recommended strategies include improving the collection and monitoring of data on women and men in decision-making at all levels, promoting shared responsibility for household and parental duties to

14 A 2007 stocktake of the implementation by CROP agencies of the CROP Gender Strategy (1998, revised 2005) found very little progress by CROP agencies in adhering to their gender commitments. 
eliminate women's time disadvantage, providing leadership training for women, taking positive action to build a critical mass of women leaders in strategic decision-making positions, and aiming for gender balance in the composition of delegations to regional and international forums (Secretariat of the Pacific Community 2005: paras 42-48; BPA, Strategic Objectives G.1 and G.2).

Integration of these types of strategies into the Pacific Plan initiatives would provide a pathway to the 'transparent, accountable and equitable' governance that is sought in the region. Further, a set of high-level agreed processes could include, among others, the establishment of a Regional Centre for Women in Leadership; support for and enhancement of undergraduate and postgraduate level gender studies programs; ${ }^{15}$ agreements on region-wide targets for gender balanced decision-making structures at all levels including in local and national governments and regional inter-governmental bodies, based on international standards; and the development of strategies for ensuring women's decisionmaking and leadership within customary, religious, community and household spheres across the region.

\section{Development}

Sustainable development is defined in the Pacific Plan as:

[T] he integration and mutual reinforcement between the three pillars of economic development, social development, and environment conservation (where conservation is defined as wise use, including protection, in some circumstances). Essential requirements for sustainable development include active stakeholder participation, poverty eradication, changing unsustainable patterns of production and consumption and managing and conserving the natural resource base for economic and social development, while maintaining the underlying ecological processes.

The Plan's eight strategic objectives under this pillar include poverty reduction and improved gender equality. However, unlike all of the other strategic objectives which have clearly defined initiatives for their achievement, neither Strategic Objective 4 (Reduced Poverty) nor 8 (Improved Gender Equality) have any initiatives attached. Rather, according to the crafters of the Pacific Plan, '[o]ther regional initiatives contribute to [them] and will be monitored and evaluated for their contribution to achieving [them]'. The document is silent on

15 This has been on the gender agenda for many years. Encouragingly, the University of the South Pacific is now embarking on a new initiative to introduce a gender studies programme. This initiative will need to be strongly supported to ensure long-term viability. 
which specific initiatives will contribute to reducing poverty and how, and the 'other regional initiatives' listed as contributing to Improved Gender Equality do not include any under Economic Growth and only one peripherally under Security. ${ }^{16}$ Further, as stated earlier, unlike other initiatives which expressly reference the need for implementation of relevant existing regional strategies and plans of action, there is no reference in the gender equality objective, nor anywhere else within the Sustainable Development goal, to implementation of the BPA or PPA. Both of these frameworks contain clear recommendations to governments for achieving gender equality, including a number of genderresponsive economic, social and environmental development strategies of direct application to any meaningful interpretation of the Pacific Plan definition of sustainable development.

It is perhaps reflective of the continued low political attention that is given to national and international commitments to gender equality that it was seen as being the eventual result of, rather than a condition precedent to, achievement of the other regional initiatives of the Pacific Plan. International analysis confirms the reverse to be true, and yet there is little practical understanding or application of the need for systematic gender and human rights analysis, budgeting and mainstreaming at the outset and through the course of all development and governance processes and frameworks in the Pacific. At the national level, women's issues are typically restricted to social sectors, usually with a social welfare or service delivery approach, rather than mainstreamed across the full range of government policy making and programming based on a human rights and gender transformative approach (Secretariat of the Pacific Community 2010a). Also reflective of the low attention given to women's issues at the highest levels, since the 2007 Vava'u Decisions and through to the 2009 Annual Progress Report gender equality as a strategic objective is not included within annual priority areas, has not been reported on, and has had no specific initiatives developed for its achievement.

The PPA and BPA, on the other hand, had as their raison d'être the elaboration of comprehensive analyses of and recommendations for achieving gender equality. If the drafters of the Pacific Plan were unclear on potential implementation strategies on Strategic Objective 8, they had only to reference these ten-year old (at the time) frameworks for inspiration. According to the BPA, for instance, the twelve 'critical areas of concern' for gender equality are: the persistent and increasing burden of poverty on women; inequalities and inadequacies in and unequal access to education and training; inequalities and inadequacies in and

16 Initiative 13.3 relating to the strengthening of law enforcement includes regional training on 'family, domestic, gender and sexual violence' and human rights. Among others, there is no mention of the need for comprehensive legislation on gender-specific security concerns, full inclusion of women in peace and security institutions and processes including police forces, or holistic measures to eliminate gender-based violence. 
unequal access to health care and related services; violence against women; the effects of armed or other kinds of conflict on women, including those living under foreign occupation; inequality in economic structures and policies, in all forms of productive activities and in access to resources; inequality between men and women in the sharing of power and decision-making at all levels; insufficient mechanisms at all levels to promote the advancement of women; lack of respect for and inadequate promotion and protection of the human rights of women; stereotyping of women and inequality in women's access to and participation in all communication systems, especially in the media; gender inequalities in the management of natural resources and in the safeguarding of the environment; and persistent discrimination against and violation of the rights of the girl child (United Nations 1996).

The PPA, which provides the regional perspective on the above critical areas as well as emerging areas of concern, notes that a pressing issue in the region is the failure of governments to provide adequate resources to women's departments. National budget allocations specifically targeted to women's affairs were found to range between 0.002 and 1 per cent (Secretariat of the Pacific Community 2005: para 28), often just enough to fund a women's affairs desk. Further, despite the cross-cutting nature of gender it is rarely treated as such in any practical sense, and women's departments are rarely included in the various sectoral meetings which have clear relevance from a gender perspective. It is no surprise that these government departments are completely unable to implement any of the BPA and PPA strategic objectives with those meagre resources and siloed government structures. The PPA goes on to recognise that the government budget is the single most important policy tool of government, mirroring in financial terms the importance governments place on different issues, and notes the poor performance throughout the region in formulating gender-responsive budgets (Ibid.: paras 29-31). Based on these findings, it provides specific strategic recommendations for governments including on appropriate staffing, resourcing and situating of national government offices for women and gender equality (Ibid.: paras 36-37).

Regional organisations, which play a major role in many aspects of the Pacific Plan's implementation, are characterised by the same barriers of inadequate institutional architecture and low attention given to gender equality commitments. Out of ten CROP agencies, only two have full-time gender positions in their staffing structure. PIFS has only one full-time position dedicated to gender issues. The organisation elected not to fill the more senior Gender Issues Adviser position that has been vacant since 2006, and as of 2009 it has taken that position out of its organisational structure altogether. Until very recently, SPC similarly has had only one permanent, dedicated gender position, although as of 2008 the Pacific Regional Rights Resource Team which focuses on human 
rights including women's human rights became a programme under SPC and the Human Development Programme is in the process of expanding its gender equality unit. None of the other CROP agencies have gender experts among their staff. Within the work of PIFS and SPC, gender equality as a cross-cutting issue is often given tokenistic attention, with no processes in place to ensure gender expertise informs high level planning, programming and budgeting decisions across sectors.

This marginalisation of national and regional institutional structures is a major obstacle to the achievement of national, regional and international commitments to gender equality including under the Pacific Plan.

Given the number of commonalities throughout the region on gender equality issues, and in light of how stretched women's departments in national governments are, a regional approach to complement and strengthen national efforts is necessary. Several of the BPA and PPA critical areas of concern need to be integrated as clear initiatives under the Gender Equality strategic objective of the Pacific Plan. At the same time, a set of agreed, high-level, multi-sectoral processes and mechanisms could, among others, seek to: significantly enhance national and regional institutions for the achievement of gender equality including through increased staffing and financial resources; develop minimum agreed standards and benchmarks for gender and human rights mainstreaming and gender budgeting within government; establish processes and timeframes for mainstreaming gender and human rights into other existing regional and national frameworks and strategies including sectoral strategies and national development strategies; develop and implement standardised multi-sectoral gender and human rights analysis tools; establish thematic sectoral working groups to develop best practices for gender-responsive law- and policy-making and programming; strengthen processes for achieving full compliance with the CROP Gender Strategy; and create regional platforms at the highest levels for monitoring and evaluating progress on gender equality and measuring the gender performance and accountability of leaders and regional institutions. A regional human rights body will also be critical for promoting and protecting women's human rights in the region, including a dedicated special mechanism on gender equality such as a special rapporteur or expert working group, as has been used with success in other regions, for example the work of the African Commission on Human and Peoples' Rights' special rapporteur on the rights of women in Africa. ${ }^{17}$

17 This special mechanism has been in place since 1998 and has been responsible for the development of a Protocol to the African Charter on Human and Peoples' Rights on the Rights of Women in Africa and for significant work with individual countries and populations on advancing women's rights. See http://www. achpr.org/english/_info/index_women_en.html 


\section{Economic Growth}

Economic growth is defined in the Pacific Plan as 'sustainable, pro-poor growth'. That is promising on its face since we know that sustainable growth and development require the participation by and accrual of benefits to both women and men, and that poverty is disproportionately experienced by females. However, the economic growth aspects of the Pacific Plan are completely gender blind. The initiatives for immediate implementation included expanding and integrating trade markets, developing an ecosystem-based fishery management framework, developing strategies for bulk petroleum purchase, enhancing regional transport services, implementing a regional digital strategy and supporting private sector mechanisms. Issues for agreement in principle or further analysis were limited to tourism and bulk purchasing of pharmaceuticals.

Not a single economic growth initiative relates to women's access to and participation in the economy, despite the region's poor performance in this area as illustrated earlier. No gender economic analysis was commissioned among the eighteen ADB-Commonwealth Secretariat working papers or otherwise. In contrast, the need for better gender specific labor force data, protection and promotion of women's employment rights and attention to the differential impacts of trade liberalisation on men and women, among others, is identified in the BPA (Strategic Objectives F1-F6) and PPA (Secretariat of the Pacific Community 2005: section D and paras 95-98). The BPA recognises that macroeconomic policies focus almost exclusively on the formal sector, fail to take into account their differential impact on women and men, and need rethinking and reform based on proper gender analysis (Strategic Objectives A.1-A.4). It also recommends that governments restructure and target the allocation of public expenditures to promote women's economic opportunities (Strategic Objective A.1).

A 2007 UNESCAP Social and Economic Survey of Asia and the Pacific found that the region as a whole loses an estimated US \$42-\$47 billion per year because of restrictions on women's access to employment opportunities and a further \$16-\$30 billion per year from gender gaps in education (UN Economic and Social Commission for Asia and the Pacific 2007). While women's right to equal access to economic participation is an end in itself and not something to be seen from a purely instrumentalist perspective, this kind of detailed analysis of the economic costs of gender inequality specifically in the Pacific Islands region should be initiated by regional leaders as part of any economic growth discussion, alongside full analysis of the particular barriers women face in accessing the economy and what women see as appropriate pathways to full economic empowerment. 
Politics, Development and Security in Oceania

Certain gender aspects need to be mainstreamed into the Pacific Plan text, such as a requirement to conduct a systematic gender analysis of trade related initiatives within the current trade agenda. A set of agreed regional processes could also help address some of the major gender deficiencies, for instance by agreeing on modalities for ensuring that analyses of women's economic rights and empowerment inform all regional economic discussions, including at Forum Economic Ministers Meetings.

\section{Conclusion}

Gender equality continues to be highly ghettoised despite its centrality to stability, security and development in the Pacific Islands region. Women's issues are at best being given tokenistic attention across much of the region, which is harmful not only to the female half of the population but to development and governance effectiveness overall. They are largely left to be dealt with by severely under-resourced and poorly placed 'gender desks' despite their primary and cross-cutting nature across the stability, security and development spectra, and despite the multiple development benefits that could accrue to the region as a whole if they were put front and centre on all high level agendas.

Squeezing neglected gender issues into pre-determined definitions and frameworks after the fact is a frustrating exercise. Going forward, regional discourse, frameworks and resource allocations need to be developed not just in consultation with women's groups but by women participating equally from the outset, in structures that they have helped conceptualise and which are free from longstanding systemic gender barriers. As a matter of priority, existing national and regional structures and processes relating to stability, security and development need to be re-conceptualised so as to ensure men's and women's needs, perspectives and human rights are equally accounted for from the outset. Women can no longer be required to chase at the heels of andocentric structures and processes that are simply not designed to reflect their different situation or address their specific concerns and aspirations.

In the interim, major gains could be achieved in this region by integrating existing, comprehensive gender equality frameworks such as the BPA and PPA into the Pacific Plan and other national and regional stability, security and development frameworks. Those gender equality frameworks address all of the same issues as the Pacific Plan (and most national development strategies) but from the perspective of women. They are the result of intensive regional and international consultation and discussion amongst gender and human rights experts within government women's departments, international agencies and civil society. Given that the Pacific Plan lacks the requisite gender perspective, 
and that the BPA and PPA lack the requisite multi-sectoral ownership, accountability and resourcing, a marriage of the frameworks would provide for a more comprehensive and inclusive regional development platform going forward.

As part of that integration, national and regional leaders should consider endorsing the development of a set of agreed regional processes for strengthening national and regional mechanisms for gender equality. Such processes should be heavily informed and guided by the BPA and PPA along with other legal and policy frameworks such as CEDAW and the CROP Gender Strategy, and should contain clear timeframes and methods for coordination. In light of the crosssectoral nature of gender issues, implementation and monitoring of the agreed processes should rest with a high-level, multi-sectoral collectivity.

These steps should be prioritised as part of the next Pacific Plan review. With the fifteenth anniversary of the PPA and BPA now upon us, and the Pacific Plan marking its fifth anniversary, 2010 would be a good time to work, and celebrate, together.

\section{References}

Asian Development Bank and Commonwealth Secretariat. 2005. Toward a New Pacific Regionalism: An Asian Development Bank-Commonwealth Secretariat Joint Report to the Pacific Islands Forum Secretariat. Volume 2. Available at http://www.adb.org/Documents/Reports/Pacific-Regionalism/default.asp

Duncan, R. 2005. 'Quantitative Assessment of the Cost of Governance Failure in Fiji Islands, Nauru, Papua New Guinea, and Solomon Islands', Working Paper 3. Asian Development Bank and Commonwealth Secretariat. Toward a New Pacific Regionalism. Volume 3: Working Papers. Available at http:// www.adb.org/sites/default/files/pacific-regionalism-vol3.pdf

Family Planning International. 2009. A Measure of the Future: Women's Sexual and Reproductive Risk Index for the Pacific 2009. Wellington.

Hassall, G. 2005. 'An Assessment of the Scope for Regional Cooperation, Integration and Collective Provision on Security Issues', Working Paper 1. Asian Development Bank and Commonwealth Secretariat. Toward a New Pacific Regionalism. Volume 3: Working Papers. Available at http://www. adb.org/sites/default/files/pacific-regionalism-vol3.pdf

Human Rights Watch. 2006. Still Making Their Own Rules: Ongoing Impunity for Police Beatings, Rape, and Torture in Papua New Guinea. Volume 18, No. 13(C) (October). 
Politics, Development and Security in Oceania

Huffer, E. 2006. 'The Pacific Plan: A Political and Cultural Critique' in J. BryantTokalau and I. Frazer (eds), Redefining the Pacific? Regionalism Past, Present and Future. Aldershot: Ashgate.

Jalal, I. 2010. Gender Equity in Justice Systems of the Pacific Island Countries \& Territories: Implications for human development. Asia-Pacific Human Development Report Background Papers Series 2010/14.

McMaster, J. 2005. 'Costs and Benefits of Deregulating Telecommunication Markets in the Pacific'. Working Paper 15. Asian Development Bank and Commonwealth Secretariat. Toward a New Pacific Regionalism. Volume 3: Working Papers. Available at http://www.adb.org/sites/default/files/pacificregionalism-vol3.pdf

Morris, J. 2005. 'Small Island States Bulk Procurement of Petroleum Products: Feasibility Study'. Working Paper 13. Asian Development Bank and Commonwealth Secretariat. Toward a New Pacific Regionalism. Volume 3: Working Papers. Available at http:/www.adb.org/sites/default/files/pacificregionalism-vol3.pdf

Pacific Islands Forum Secretariat. 2005a. The Pacific Plan for Strengthening Regional Cooperation and Integration ( revised 2007).

Pacific Islands Forum Secretariat. 2005b. The Pacific Plan Background Papers, Background Paper 1: Pacific Plan Task Force Terms of Reference.

Pacific Islands Forum Secretariat. 2007. Thirty-eighth Pacific Islands Forum Communiqué. Nuku'alofa, Tonga, 16-17 October 2007, Annex A: Vava'u Decisions on the Pacific Plan. Available at http://www.forumsec.org. $\mathrm{fj} /$ resources/uploads/attachments/documents/2007\% 20Forum \% 20 Communique, \%20Vava\%27u,\%20Tonga,\%2016-17\%200ct.pdf

Pacific Islands Forum Secretariat. 2008. Thirty-ninth Pacific Islands Forum Communiqué. Alofi, Niue, 19 - 20 August 2008. Available at http://www. forumsec.org/_resources/article/files/FINAL \%202008\%20Communique.pdf

Pacific Islands Forum Secretariat. 2009. Fortieth Pacific Islands Forum Communiqué. Cairns, Australia 5 - 6 August 2009. Available at http:// www.forumsec.org.fj/pages.cfm/newsroom/press-statements/2009/finalcommunique-of-40th-pacific-islands-forum-cairns.html

Secretariat of the Pacific Community. 2005. Revised Pacific Platform for Action on Advancement of Women and Gender Equality 2005 to 2015: A Regional Charter. Noumea, New Caledonia. 
Secretariat of the Pacific Community. 2009. Ensuring approaches to maternal health in the Pacific are evidence-based, human rights- and human developmentbased and multi-sectoral, Submission to the New Zealand Parliamentarians Group on Population and Development Open Hearing on Maternal Health in the Pacific, 21 September 2009.

Secretariat of the Pacific Community. 2010a. Beijing +15 : Review of progress in implementing the Beijing Platform for Action in Pacific Island countries and territories. Noumea, New Caledonia.

Secretariat of the Pacific Community. 2010b. Transforming Power Relations: Equal status of women and men at the family level in the Pacific. Advocacy brief. Available at http://www.spc.int/hdp/index.php?option=com_ docman\&task=cat_view\&gid $=58 \&$ Itemid $=44$

Secretariat of the Pacific Community and Government of Kiribati. 2010. Kiribati Family Health and Support Study: a study on violence against women and children. Noumea, New Caledonia.

Secretariat of the Pacific Community and Government of Republic of Marshall Islands. 2008. Marshall Islands Demographic and Health Survey 2007. Noumea, New Caledonia.

Secretariat of the Pacific Community and Government of Solomon Islands. 2009. Solomon Islands Family Health and Safety Study: a study on violence against women and children. Noumea, New Caledonia.

Secretariat of the Pacific Community and Government of Tuvalu. 2009. Tuvalu Demographic and Health Survey 2007. Noumea, New Caledonia.

Secretariat of the Pacific Community, United Nations Population Fund, and Government of Samoa. 2006. The Samoa Family Health and Safety Study. Noumea, New Caledonia.

Stege, K., et al., Land and Women: The Matrilineal Factor. The cases of Republic of Marshall Islands, Solomon Islands and Vanuatu, Pacific Islands Forum Secretariat, Suva, 2008.

UNICEF, UNESCAP and ECPAT. 2006. Commercial Sexual Exploitation of Children (CSEC) and Child Sexual Abuse (CSA) in the Pacific: A Regional Report. UNICEF Pacific. Suva.

United Nations. 1996. Report of the Fourth World Conference on Women, Beijing, 4-15 September 1995. UN Doc. A/CONF.177/20/Rev.1. 
Politics, Development and Security in Oceania

United Nations Economic and Social Commission for Asia and the Pacific. 2007. Economic and Social Survey of Asia and the Pacific 2007. Surging Ahead in Uncertain Times. New York: United Nations. 